\title{
From the Cape to Canton: The Dutch Indian Ocean World, 1600-1800 - A Littoral Census
}

\author{
Markus Vink
}

To cite this article: Vink, Markus. "From the Cape to Canton: The Dutch Indian Ocean World, 1600-1800 - A Littoral Census." Journal of Indian Ocean World Studies, 3 (2019), pp. 13-37.

More information about the Journal of Indian Ocean World Studies can be found at: jiows.mcgill.ca

(c) Markus Vink. This is an Open Access article distributed under the terms of the Creative Commons License CC BY NC SA, which permits users to share, use, and remix the material provide they give proper attribution, the use is non-commercial, and any remixes/transformations of the work are shared under the same license as the original. 


\title{
From the Cape to Canton: The Dutch Indian OCEAN World, 1600-1800 - A Littoral Census
}

\author{
Markus Vink \\ SUNY, Fredonia
}

\section{Abstract}

As an exercise in trans-oceanic history, this article focuses on the Dutch Indian Ocean World in the seventeenth and eighteenth centuries from the Dutch East India Company or VOC's permanent colony at Cape Town, South Africa, in the Far West to its seasonal trading factory at Canton (Guangzhou), in the Far East. It argues that the 'seismic change' after 1760 noted by Michael Pearson and associated with the British move inland from their Bengal 'bridgehead' should be extended to the contemporary polycentric Dutch expansion into the interior of, most notably, South Africa, Ceylon, Java, and Eastern Indonesia. Demographic measuring points include the number of Dutch citizens and subjects, comprising European settlers, mixed peoples, and indigenous populations; and: the size and composition of the population of central nodal places in the Dutch Indian Ocean thalassocratic network in the late seventeenth and late eighteenth centuries. By the end of the period, both 'John Company' (EIC) and 'Jan Kompenie' (VOC) effectively were, to some extent, reversing the colonial gaze inland turning from maritime merchants into landlords and tax collectors. These seismic changes with multiple epicenters were the harbinger of tidal waves about to sweep both the littoral and interior of the modern Indian Ocean World.

Michael Pearson features prominently among the early representatives of the new thalassology' of the Indian Ocean World emerging in the 1980s. Focusing on ocean and sea basins as meaningful units of analysis, the majority of studies in the 'new thalassology' of the Indian Ocean Basin are circum-oceanic or trans-oceanic in perspective. Circumoceanic history provides a comprehensive history of the Indian Ocean as a distinct zone of exchange, circulation, and transmission. Trans-oceanic history is the comparative history of maritime worlds, assuming the existence of natios and states, societies and economic formations, ideas and cultural practices, as well as ecosystems and environments 
connected by circulation and network flows, which should inspire further comparisons with other Indian Ocean histories. ${ }^{1}$

The following is an exercise in trans-oceanic history, focusing on the Dutch Indian Ocean World in the seventeenth and eighteenth centuries formed by the settlements of the Dutch East India Company (briefly VOC after its Dutch initials), one of the great northern European chartered companies in the age of mercantilism, from the VOC's permanent colony at Cape Town, South Africa, in the Far West to its seasonal trading factory at Canton (Guangzhou), China, in the Far East. As such, it combines Pearson's conceptualizations of the 'large focus' of the 'common view' of the Indian Ocean World, stretching 'from Cape of Good Hope ... to the easternmost end of Indonesia, and up into the South China Sea', and his amphibious 'littoral societies', extending inwards into the interior with 'porous boundaries acting as filters through which the salt of the sea is gradually replaced by the silt of the land'.

Pearson duly notes the geographical and chronological variations within the Dutch Indian Ocean World stressing the 'atypical' impact of the Dutch in the spice trade. ${ }^{3}$ Though the early modern Indian Ocean was 'a world beginning to be integrated', the overall effects of the European presence over its first 250 years on the Indian Ocean, its trade, even its politics, was 'limited'. Not until the 1760 s, Pearson asserts, did a 'seismic change' occur when the British moved inland acquiring revenue rights in Bengal. ${ }^{4}$

This article argues that the 'seismic change' after 1760 noted by Pearson and associated with the British move inland from their Bengal 'bridgehead's should be extended to the contemporary polycentric Dutch expansion in, most notably, South Africa, Ceylon, Java, and Eastern Indonesia. It examines the concept of a Dutch thalassocratic empire, a 'world on the move' inland in the eighteenth century, by measuring the Dutch littoral footprint and sizing up Dutch activities in areas where they controlled territory and wielded actual jurisdiction over subject populations.

The term 'Dutch' serves as a rather loose label of convenience consisting of two components: the Dutch East India Company and its servants overseas, including numerous Germans or Hollandgänger and other foreigners ${ }^{7}$; and: European settlers,

\footnotetext{
1. For a succinct historiography: Markus Vink, "Indian Ocean Studies and the "new thalassology", Journal of Global History 2, 1 (2007), 41-62.

2. Michael Pearson, "Introduction: Maritime history and the Indian Ocean World", in Trade, circulation and flow in the Indian Ocean World, ed. Idem (New York: Palgrave, 2015), 3; Idem, "Littoral society: A case for the coast", The Great Circle 7, 1 (1985), 1-9; Idem, “'Littoral society: The concept and the problems", Journal of World History 17, 4 (2006), 353-373; Idem, The Indian Ocean, (London and New York: Routledge, 2003), 37-45.

3. Pearson, The Indian Ocean, 144-153.

4. Idem, 113, and 153.

5. Peter J. Marshall, Bengal: The British bridgehead: Eastern India 1740-1828 (Cambridge: Cambridge University Press, 1987).

6. A play on Anthony John R. Russell-Wood, The Portuguese empire, 1415-1808: A world on the move (Baltimore: Johns Hopkins University Press, 1998).

7. Double counting those taking multiple trips, about half of the almost 1 million $(973,000)$ people leaving the Dutch Republic for the East Indies in the service of the VOC between 1602 and 1795 were foreigners.
} 
mixed peoples (mestizos, castizos, etc.), and free and unfree Afro-Asian populations, including European and indigenous citizens, Company subjects, and residents, in areas under direct Dutch jurisdiction. Littoral demographic measuring points include the number of Dutch citizens and subjects, comprised of European settlers, mixed peoples, and indigenous populations, along with the size and composition of the population of central nodal places in the Dutch Indian Ocean thalassocratic network.

It will be argued that the Dutch Indian Ocean World was both a mouse-deer (kanchil) and a tiger when compared with its regional contemporaries. Similar to the British in Bengal, the VOC (reluctantly) moved inland to become an imposing presence in South Africa, Ceylon, and Java, and to a lesser extent Eastern Indonesia, while elsewhere it paled in comparison with the powerful and populous early modern land-based empires. Thus, by the late eighteenth century there was, to paraphrase Pearson, much more 'silt of the land' and much less 'salt of the sea' in the 'littoral societies' of the Dutch Indian Ocean World. In the course of the eighteenth century, moreover, it became increasingly integrated into the 'Greater Indian Ocean' through the convergence of, among others, various long-term political and demographic processes.

Few Company historians, with the noted exception of Jur van Goor, ${ }^{8}$ have endeavored to compile a comprehensive census of the Dutch Indian Ocean World, as a project of this nature runs into a number of daunting definitional and numerical issues. First, many recent studies have pointed to the disparity between the attempts at racial and ethnic engineering and classification by VOC administrators and the permeability of boundaries in reality. Far from essentialist, ethnic identities were, at least to some degree, contingent and constructed. Europeans overseas (largely single males), for instance, most notably the 'stayers' (blijvers) as opposed to the 'movers' (trekkers), from the 'singlewalking' eenlopendes in the Cape Colony to the 'bachelor' budjang in the East Indies, could and did 'go native', just as 'whitening' or localization were options for indigenous or mixed peoples, Peranakan Chinese, local Malays, Asian Christians or Mardijkers, and others in the pre-modern era by adopting 'major codes' of primordiality, civility, and sacredness. Though the VOC authorities did employ legal-ethnic categories and applied a 'color bar' or exclusionary mechanisms, being 'Dutch' or considered 'white' and concomitant career opportunities were, besides skin color, contingent on a number of other factors- Protestant religion and Christian bourgeois life-style, social background, a Dutch education, along with connections and family ties. Expressed by the Council of Dordt in 1618-1619, Dutch Calvinism espoused, in theory if not in practice, the ideal of assimilation rather than apartheid. ${ }^{9}$

\footnotetext{
8. Even Van Goor's 'survey' for the second half of the eighteenth century is admittedly incomplete as it does not include Java's Northeast Coast, the Coromandel Coast, and other VOC 'territorial comptoirs'. See: Jur van Goor, Prelude to colonialism: The Dutch in Asia (Hilversum: Verloren, 2004), 23; Idem, De Nederlandse koloniën: Geschiedenis van de Nederlandse expansie, 1600-1975 (The Hague: Sdu, 1994), 135.

9. See: Ulbe Bosma and Remco Raben, Being 'Dutch' in the Indies: A history of creolisation and empire, 1500-1920
} 
Second, rather than alien Fremdkörper, Indian Ocean World and Company scholars have focused on synergetic concepts such as hybridity, dialogue, and localization. The various 'comptoirs' of the Dutch Indian World were adapting and assimilating into, and intricately interconnected with, their surrounding milieu. These osmotic processes were facilitated by trade relations, social interaction, cross-cultural encounters, political contacts, and the control of considerable territory, reminiscent of Sugata Bose's 'hundred frontiers' or 'horizons', 'some political, some economic, some cultural.' ${ }^{10}$ The issue of interconnectedness is compounded by the fact that instead of modern multinationals, the East India Companies have been styled 'façades' (Holden Furber) behind which an internationally oriented trading community was hidden, or 'carapaces' (Sanjay Subrahmanyam), institutions pursuing their corporate aims while at the same time being 'used by other actors for their own [private] ends."

Third, many scholars have rightfully pointed to the ambivalent nature of the legal status of the conglomerate of Company 'territories' (conquered lands, feudatory vassalstates, tributary domains, and so forth), to which local peoples were subject to Dutch writ in various degrees. This ambivalence was then complicated by indigenous rulers' interpretations and perceptions of the exact nature and meaning of agreements, which were often at variance with that of the (sometime less than) 'Laudable' (Loffelijcke) Company in what amounted to 'a song of truth and semblance.'.

Apart from definitional issues, there are also weighty numerical problems. The figures presented here, considered as snapshots taken at one specific moment, mask shortterm violent upswings and virulent downturns caused by human and natural causes, from military conflicts to epidemic diseases. Military emergences, for instance, could lead to temporary surges in the form of a rapid deployment force drawing on the vast pool of men and materiel (corps de reserve) ${ }^{13}$ held in store at the Company's Asian headquarters in Batavia. Mortality rates, high under ordinary circumstances in the Dutch tropics in Asia, could reach catastrophic levels due to the combined impact of malaria, typhus, dysentery, beriberi, and other waterborne illnesses. The resultant decrease in Company subjects and loss of personnel merely exacerbated the anemic effects caused by the continuous

\footnotetext{
(Athens: Ohio University Press, 2008); Markus Vink, Encounters on the Opposite Coast: The Dutch East India Company and the Nayaka state of Madurai in the seventeenth century (Leiden and Boston: Brill, 2015), 34, and 112-113.

10. Sugata Bose, A hundred horizons: The Indian Ocean in the age of global empire (London and Cambridge: Harvard University Press, 2006), 4; Joop de Jong, De waaier van het fortuin: De Nederlanders in Azië en de Indonesische Archipel, 1595-1950 (The Hague: Sdu, 1998), 15, 19, 42, 46, 120-121, 135 et seq. See also: Van Goor, De Nederlandse koloniën, 130; and: Femme Gaastra, The Dutch East India Company: Expansion and decline (Zutphen: Walburg Pers, 2003), 78-79. 11. 'Sanjay Subrahmanyam, "Introduction: The Indian Ocean World merchant and Ashin Das Gupta", in The world of the Indian Ocean merchant, 1500-1800: Collected essays of Ashin Das Gupta, ed. Uma Das Gupta (Delhi: Oxford University Press, 2001), 17; Holden Furber, Rival empires of trade in the Orient, 1600-1800 (Minneapolis: University of Minnesota Press, 1976), 227.

12. Van Goor, De Nederlandse koloniën, 135; De Jong, De waaier van het fortuin, 65, 71, 94-95, and 104.

13. Judith Schooneveld-Oosterling ed., Generale missiven van gouverneurs-generaal en raden aan Heren XVII der Verenigde Oostindische Compagnie (The Hague: Instituut voor Nederlandse Geschiedenis, 2007), XII, 291.
} 
hemorrhaging of the VOC's body politic or debilitating 'drain' due to desertion. ${ }^{14}$ Moreover, the quantitativematerials or 'hard' data presented in VOCcorrespondence, most notably census materials, are either (partial) guesstimates by Company officials or based on information provided by indigenous authorities with no particular interest in inflating numbers. Underestimating or underreporting was common practice as population tallies were often compiled for fiscal purposes.

Lastly, the VOC, if not impetuous local administrators then at least the calculating board of directors at home, showed a general unwillingness to assume control over indigenous people under its sway and incur the concomitant administrative overheads. This 'reluctant imperialism' meant that de facto VOC control in some areas could be considerably more extensive than actually claimed on paper. ${ }^{15}$

To characterize, however, any numerical exercise as 'somewhat pointless' is to prematurely throw the proverbial Dutch baby out with the Indian Ocean bathwater. ${ }^{16}$ Warts and all, il faut compter: to categorically dismiss the mine of statistical data buried in the VOC repositories a priori would be an egregious mistake. Rather than 'numbers from nowhere, ${ }^{17}$ they are, at the very least, approximations providing an indication of scale or relative size. Moreover, they also constituted the basis for the formulation of VOC corporate policies and individual decisions affecting large groups of people. Paranoically obsessed with preserving the reputation of the 'Laudable' Company among 'feigned friend and public enemies', VOC leadership often felt compelled to act decisively to defend the 'honor of the polity' when it deemed the interests of its perceived subjects, and hence its own reputation and honor, were being diminished. ${ }^{18}$ Nevertheless, the numbers presented

14. Vide the numerous ordinances issued against desertion and the lists of deserters annually compiled by the individual VOC settlements, such as Malabar and Bengal, in the Company archives. The VOC routinely concluded treaties with indigenous rulers and other European powers in Asia, which included cartel clauses dealing with the mutual exchange of deserters and runaways.

15. The characterization of the VOC as a reluctant imperialist has become a virtual axiom among Company historians. See, for instance: Luc Nagtegaal, Riding the Dutch tiger: The Dutch East India Company and the Northeast Coast of Java, 1680-1743 (Leiden: KITLV Press, 1996), 15-16; Gaastra, The Dutch East India Company, 60-65; De Jong, De waaier van het fortuin, 45, and 83-106; Kwee Hui Kian, "How strangers became kings: Javanese-Dutch relations in Java, 1600-1800", Indonesia and the Malay World 36, 105 (2008), 293-307; Doreen Greig, The reluctant colonists: Netherlanders abroad in the 17th and 18th centuries (Assen and Wolfeboro: Van Gorcum, 1987); Els Jacobs, Koopman in Azië: De handel van de Verenigde Oost-Indische Compagnie tijdens de 18de eeuw (Zutphen: Walburg Pers, 2000), 179-183.

16. Gijs Kruijtzer, "European migration in the Dutch colonial sphere", in Dutch colonialism, migration, and cultural heritage: Past and present, ed. Gert Oostindië (Leiden: KITLV Press, 2008), 122.

17. David Henige, Numbers from nowhere: The American Indian contact population debate (Norman: University of Oklahoma Press, 1998).

18. For the importance of the concept of personal 'honor' on the individual level and 'honor of the polity' in international relations as part of the common 'moral geography' of the Dutch Republic: Erik Swart, "Defeat, honour and the news: The case of the fall of Breda (1625) and the Dutch Republic", European History Quarterly 46, 1 (2016), 6-26; Lotte van de Pol, The burgher and the whore: Prostitution in early modern Amsterdam (Oxford: Oxford University Press, 2011), 43-50; Willem Frijhoff and Marijke Spies, 1650: Hard-won unity (Assen: Van Gorcum, 2004), 187-190; Hans de Waardt, "De geschiedenis van de eer en de historische antropologie”, Tijdschrift voor Sociale Geschiedenis 23, 3 (1997), 334-354; Herman Roodenburg, "Eer en oneer ten tijde van de Republiek: Een tussenbalans", Volkskundig Bulletin 22 (1996), $129-149$. VOC correspondence is awash with policy discussions related to notions of reputation, prestige, honor, status, and respect. 
here are 'soft' and suggestive rather than hard and conclusive.

The body of text assumes the form, in rough geographical order from West to East, of a littoral survey of the 'territorial comptoirs' or VOC settlements in the Indian Ocean World where it exercised varying degrees of authority over subject populations. In each of these 'comptoirs' we will look at the number of Dutch subjects in general, and the size and composition of populations in the main urban centers or central places in the respective settlement in particular. The conclusion (in conjunction with Tables 1 and 2) will summarize the findings and try to make sense of the aggregate data by focusing on the late seventeenth and late eighteenth centuries and the long-term processes involved.

\section{The Far West: The Cape Colony}

Despite the impact of diseases, such as the repeated outbreak of smallpox epidemics (1713, 1755, 1765-1769), and measles and fevers (1739-1741), the Cape Colony population expanded rapidly, especially in the eighteenth century, mostly through natural increase of the free population (including small numbers of European knechten or servants and free blacks) along with the large-scale import and creolization of slaves. Between 1652 and 1808, for instance, approximately 63,000 slaves were imported to the Cape from four major regions: mainland (mostly East) Africa, Madagascar and Mascarene Islands (Mauritus and Réunion), India, and Indonesia. As a result, the colony's population increased from 360 in 1658 to 2,382 in 1702 (including 850 or 35.68 percent slaves), accelerating incrementally in the eighteenth century to 12,340 (including 5,327 or 43.17 per cent slaves) in 1750 and 31,792 (including 16,839 or 52.96 percent slaves) in $1795 .{ }^{19}$

Ironically, the indigenous San hunter-gatherer and Khoikhoi pastoralist populations were classified as 'outsiders' or 'aliens' and not considered subjects of the VOC. San hunter-gatherers may never have exceeded 20,000, whereas estimates of the number of Khoikhoi in the mid-seventeenth century vary between 100,000 and 200,000. A more inclusive Cape census was conducted in 1805, after the collapse of the VOC, under the auspices of the Batavian Republic. The total population of the Cape Colony was reported as 75,308, including 25,757 Europeans (excluding soldiers) or 34.20 percent, 29,545 slaves (39.23 percent), but only 20,006 indentured Khoikhoi 'Hottentots', mixed 'Bastards', and San 'Bushmen' (26.57 percent). This demographic collapse was the result of the combined impact of diseases, such as smallpox, measles, and rinderpest epidemics,

\footnotetext{
19. Robert Ross and Pieter van Duin, The economy of the Cape in the eighteenth century (Leiden: Centre for the History of European Expansion, 1987), 112-115; Robert Shell, Children of bondage: A social history of the slave society at the Cape of Good Hope (Hanover and London: Wesleyan/University Press of New England, 1994), 40-41; Nigel Worden, The chains that bind us: A history of slavery at the Cape (Kenwyn: Juta, 1996), 23, 26, and 43; Van Goor, De Nederlandse koloniën, 116; James Armstrong and Nigel Worden, "The slaves, 1652-1834", in The shaping of South African society, 1652-1840 ed., Ralph Elphick et al. (Middletown: Wesleyan University Press, 1988), 120-121, and 130; Markus Vink, "'The world's oldest trade': The Dutch Indian Ocean slave trade in the seventeenth century", Journal of World History 14, 2 (2003), 131-177.
} 
settler violence in the form of official and Boer commandos, intermarriage with other groups, and incorporation into colonial society. ${ }^{20}$

Cape Town was the primate city of the burgeoning colony. From very humble beginnings, its population grew from 360 in the late 1650s (1658), to more than 1,500 in $1685,3,157$ in 1731, and c. 4,200 in 1750, to some 7,000 at the end of the eighteenth century (1795). Similar to all central places in the Dutch Indian World, Cape Town was a true slave society: in 1731 the 1,333 VOC and private slaves accounted for 42.22 percent of the population. It was one of the few central places in the Dutch Indian Ocean World where the 'European' component held up and even increased rapidly in the eighteenth century with 1,624 Europeans and mestizos or 51.44 per cent in the same year. ${ }^{21}$ The Cape census of 1805 lists 16,984 residents, including 9,129 slaves (53.75 percent), 6,273 Europeans (36.93 percent), and 1,582 (9.31 percent) non-European free population consisting of 'Asiatics', free blacks, and 'Hottentot' Khoikhoi. ${ }^{22}$

\section{The 'Western Districts': Ceylon, Malabar, and Coromandel}

In older publications, the number of indigenous subjects both Sinhalese and Tamils, on Ceylon was held to be 230,000 in the late seventeenth century. This number was to increase to more than 360,000 , including some 200,000 in the northern province of Jaffna alone, by $1794 .{ }^{23}$ In several recent publications, however, combining VOC records and secondary literature, Pim de Zwart has revised these numbers upwards significantly, emphasizing, though, that they are 'preliminary estimates based on a number of assumptions and a limited amount of evidence.' In 1684, the total population of the three maritime provinces of Ceylon - Jaffna $(155,592)$, Colombo $(54,388)$, and Galle $(68,118)$ - had a combined

20. Census of the colony of the Cape of Good Hope 1904 (Cape Town: Cape Times, Limited, 1904), v; Rodney Davenport and Christopher Saunders, South Africa: A modern history. 5th edn. (Basingstoke: Palgrave Macmillan, 2000), 6, and 8; S. Daniel Newmark, The South African frontier: Economic influences, 1652-1836 (Palo Alto: Stanford University Press, 1957), 10-11; Ralph Elphick, Kraal and castle: Khoikhoi and the founding of white South Africa (New Haven: Yale University Press, 1977), 23; Monica Wilson, "The hunters and herders", in The shaping of South African society, 68. Both Elphick and Wilson are revisions of earlier estimates $(45,000-50,000)$ for the number of Khoikhoi: George McCall Theal, History of South Africa under the administration of the Dutch East India Company, 1652-1795 (London: Swan Sonnenschein \& Co., 1897), I, 126.

21. Nigel Worden, Elizabeth van Heyningen, and Vivian Bickford-Smith, Cape Town: The making of a city (Hilversum: Verloren, 1998), 26, and 50; Ad Biewenga, De Kaap de Goede Hoop, een Nederlandse vestigingskolonie, 1680-1730 (Amsterdam: Prometheus/Bert Bakker, 1999), 29; Ross and Van Duin, The economy of the Cape, 10, and 126; Gerrit Schutte, "Company and colonists at the Cape, 1652-1795", in The shaping of South African society, 300.

22. Census of the colony of the Cape of Good Hope 1904, vi.

23. Generale missiven, IX, 539; XIII, 183, 437, 444, 577, and 583; XIV, Band 1, 262, and 439; XIV, Band 2, 642, 840, and 1022; Pieter van Dam, Beschryvinge van de Oostindische Compagnie, ed. Frederik W. Stapel (The Hague: Nijhoff, 1932), Part 2.2, 314-315; Jur van Goor, Jan Kompenie as schoolmaster: Dutch education in Ceylon, 1690-1795 (Groningen: Wolters-Noordhoff, 1978), 121, and 160-161; Sinnappah Arasaratnam, "Protestants: the first phase, 1650-1880", in Christianity, traditional cultures and nationalism: The South Asian experience (Jaffna: Jaffna College, 1978), 19; Albert van den Belt, Het VOC bedrijf op Ceylon: Een voorname vestiging van de Oost-Indische Compagnie in de 18de eeuw (Zutphen: Walburg Pers, 2008), 251; Reindert Kromhout ed., Het machtige eyland: Ceylon en de VOC (The Hague: Sdu, 1988), 24, and 43; Jacobs, Koopman in Azië, 41; Van Goor, De Nederlandse koloniën, 135. 
population of 278,098 (including 216,296 Christians), while the kingdom of Kandy, holding the island's interior together with some coastal strips in the east and west, accounted for 539,592. De Zwart, pace N.K. Sarkar, argues that the 817,000 total for Ceylon is to be corrected for 'serious under-estimation' to $1,291,087$. In 1789, the three maritime provinces combined had a population of 817,000 (including 347,144 Christians) whereas 'rump' Kandy now had merely 285,000. The total for Ceylon of 1,102,000 again is revised upwards to $1,788,000$. How precisely these additional upward corrections affect the actual number of VOC subjects is left unanswered. De Zwart distinguishes three periods in the island's demographic history: the early period of Dutch rule (until 1710), which saw only limited population growth due to the wars with the kingdom of Kandy; a period of 'relatively fast' population growth between 1710 and 1760 leading to population pressure and social unrest by the late 1750s; and lastly, including a brief drop during the KandyDutch War (1760-1766), a period of slower growth between the 1760s to $1790 .{ }^{24}$

Besides 'Ceylon proper', the Ceylon government also controlled the southeast India littoral or 'the Company's lowlands on the Opposite Coast' including the low-caste Roman Catholic Parava fishermen community. In 1665, a 'rough calculation' by then Captain Hendrik van R(h)eede counted 18,210 Paravas, whereas Joan Nieuhoff, the Dutch Chief of Tuticorin between 1664 and 1665, estimated there were 20,000 living in the 'port-hamlets' scattered along the Ramnad and Madurai Coasts, most notably Tuticorin, Manappad, and Punnaikayal. ${ }^{25}$

Ceylon's most important urban center by far was Colombo, second in size only to Batavia among all the central places in the Dutch Indian Ocean World. The total population of its center (Fort, Town or Pettah) and conurbation (suburbs and surrounding villages in the Four Gravets) roughly doubled from over 13,000 in 1688 (including 2,650 outside the walls) to some 27,000 (5,600 intramuros within the Fort and Town, and 21,700 in the Four Gravets) by 1814. The greatest expansion of the population during the eighteenth century occurred in the surrounding countryside of the Four Gravets accompanied by a growing interest in private agricultural enterprise and large estates in the interior. The other two maritime district capitals, Jaffna and Galle, were secondary-rank cities with 1,062 (1694) and 1,841 (1760) inhabitants, respectively. Though reliable estimates for the two cities on the eastern coast, Trincomalee and Batticaloa, are conspicuously lacking, the population of these cities combined may have been less than 10,000. The Dutch central places on Ceylon were true slave societies: in 1694, for instance, the 1,787 slaves (out of 3,352 ) made up more than half (53.31 per cent) of the population of Colombo's Fort and

\footnotetext{
24. Pim de Zwart, Globalization and the colonial origins of the Great Divergence: Intercontinental trade and living standards in the Dutch East India Company's commercial empire, c. 1600-1800 (Leiden and Boston: Brill, 2016), 159, and 248-253; Idem, "Population, labour and living conditions in early modern Ceylon: An empirical contribution to the divergence debate", Indian Economic and Social History Review 49, 3 (2012), 366, and 376-380; N.K. Sarkar, The demography of Ceylon (Colombo: Ceylon Government Press, 1957), 18, and 22. Sarkar's numbers are used by Colin McEvedy and Richard Jones, Atlas of world population (Londen: Allen Lane, 1978), 186.

25. Generale Missiven, XIV, Band 2, 637; Vink, Encounters on the Opposite Coast, 91, and 163-164.
} 
Town in 1694; in 1760, the 393 slaves (out of 1,841) accounted for 'only' 21.35 percent of the population of Galle. ${ }^{26}$

Apart from the former Portuguese possessions and numerous tracts of land scattered around Fort Cochin and elsewhere, by the treaty of 1663 the Company also claimed jurisdiction over the kingdom's Roman Catholic Christians on the Malabar Coast, most notably the low-caste Mukkuva fishermen, who came under the Bishop's see at Cochin. The 1743 Treaty of Mavelikara between the Dutch and Travancore extended the VOC's jurisdiction to Christians residing in the Raja of Travancore's territory, though this point was later contested by its ruler Marthanda Varma. In 1664, in the immediate aftermath of the conquest, an estimated 8,000 indigenes, including 4,000 topazes or IndoPortuguese, resided around the town of Cochin. In 1795, following their takeover of the Dutch establishments along the Malabar coast, the English estimated that some 12,000 'Portuguese' and Malabar Christians lived under Dutch protection at Vaipin, an island north of Cochin, and on the outskirts of Fort Cochin. ${ }^{27}$

Fort Cochin and nearby Mattancherri (Cochim de Cima or 'native Cochin') represented a 'twin establishment' emblematic for the social and economic permeability of urban walls. In 1664, with most of its infrastructure in ruins, the intramuros population of Fort Cochin was probably less than 1,000, but numbers rebounded within a few decades to 1,845 in 1687 , and 2,216 in 1697 . It would show a slight decline in $1730(1,682)$ and recover to 2,040 in 1760, and 2,317 in 1790. A major factor affecting the town's prosperity was the 'reversal of the northern trade' after 1730, the arrival of mostly Arabian merchants from the areas around the mouth of the Persian Gulf in search for alternative markets due to the violence of war in Mocha, Persia, and northwest India in the 1720s. This boom lasted until Travancore managed to build its own harbor in 1781 to break the Company pass system. The former merchant-warrior turned into landlord shifting its attention from the region's black pepper to brown soil. Fort Cochin was also a true slave society

\footnotetext{
26. Gerrit Knaap, "Europeans, mestizos, and slaves: The population of Colombo at the end of the seventeenth century", Itinerario 5, 2 (1981), 88-94; Remco Raben, "Batavia en Colombo: The ethnic and spatial organization of two colonial cities, 1600-1800". Unpublished Ph.D. Thesis (Leiden: University of Leiden, 1996), 103-108; Alicia Schrikker, Dutch and British colonial intervention in Sri Lanka, 1780-1815: Expansion and reform (Leiden: Brill, 2007), 44-45; Lodewijk Wagenaar, Galle: VOC-vestiging in Ceylon (Amsterdam: De Bataafsche Leeuw, 1994), 36, and 46; Rik van Welie, "Patterns of slave trading and slavery in the Dutch colonial world", in Dutch colonialism, migration and cultural heritage, 214; Hendrik de Vos tot Nederveen Cappel, "De dienaren van de V.O.C. teelden in Ceylon vele kinderen bij Europese, mestiesen, castiesen, toepassen, swarte, Bandanese, Maleise en Singalese vrouwen", Gens Nostra 33 (1978), 308-315; Markus Vink, "Dutch East Indies", in Europe, 1450-1789: Encyclopedia of the early modern world, ed. Jonathan Dewald (New York: Charles Scribner's Sons, 2004), II, 192-193; Idem, “'The world's oldest trade”", 148; De Zwart, "Population, labour and living conditions", 379.

27. Jan Ernst Heeres ed., Corpus diplomaticum Neerlando-Indicum (The Hague: Nijhoff, 1931), II, 244; VI, 5; Hugo 's Jacob ed., De Nederlanders in Kerala, 1663-1701: De memories en instructies betreffende het commandement Malabar van de Verenigde Oost-Indische Compagnie (The Hague: Nijhoff, 1976), LIII-LIV; Idem, The rajas of Cochin, 1663-1720: Kings, chiefs and the Dutch East India Company (New Delhi: Munshiram Manoharlal Publishers, 2000), 36, and 41-42; Van Goor, De Nederlandse koloniën, 114; Anjana Singh, Fort Cochin in Kerala, 1750-1830: The social condition of a Dutch community in an Indian milieu (Leiden and Boston: Brill, 2010), 33, 39-40, and 177; Mark de Lannoy, The Kulasekhara Perumals of Travancore: History and state formation in Travancore from 1671 to 1758 (Leiden: CNWS Publications, 1997), 109-110.
} 
comprising more than half of its population: 1,083 out of 2,063 (52.50 percent) in 1740 and 1,299 out of 2,317 (56.06 percent) in 1790. As in most other 'Dutch' central places, its European population remained stagnant or dwindled over the course of the eighteenth century: in 1740, there were only 115 (all male) European households (5.57 percent) against 155 (6.69 percent) in 1790. Mixed populations (mestizos and castizos) accounted for 494 (23.95 percent) in 1740 and 649 (28.01 percent) in $1790 .{ }^{28}$

In view of the more formidable indigenous political structures, and its own more restricted commercial aims, the VOC did not have any significant territorial possessions along the east coast of India. Through a selective display of maritime power and the perceptions of indigenous rulers of the politico-economic benefits of its presence, however, it did manage to hold certain ports and weaving villages under temporary and permanent leases against a fixed annual compensation. In exchange, the Company could collect all local revenues, act according to its wishes, even administer justice, and claim import and export monopolies of the most important trade goods. ${ }^{29}$ Nevertheless, actual Dutch subjects were limited to a few forts and villages in the immediate vicinity.

The two main Dutch central places along the Coromandel Coast were Pulicat and Nagapatnam, serving as the Company's headquarters before and after 1690, respectively. Information on the size of Pulicat and Nagapatnam, and the limited number of VOC subjects is (at least so far) unavailable, but there are a few scattered clues. Pulicat in the early seventeenth century was a town in decline, with various estimates ranging between just over 10,000 (pace Sanjay Subrahmanyam) or only 2,000-3,000 residents (Om Prakash). The founding of a Dutch trading factory in 1610 and subsequent establishment of the seat of the Dutch government at Fort Geldria (built in 1613) must have reversed Pulicat's sagging fortunes, which prospered until the late seventeenth century, and the town and neighboring villages under Dutch control may have held anywhere between 5,000 and 10,000 residents during this time. ${ }^{30}$

Following its capture from the Portuguese in 1658, Nagapatnam itself was described as an 'incredibly neat and well-fortified small town'. In a highly exaggerated claim, Superintendent Rijckloff van Goens waxed lyrically that Chiormandelan, the 'outer city' of Nagapatnam, in 1674 contained over 100,000 inhabitants, and could be turned into a 'inn and free city for all those persecuted by the evil Gentile and Moorish governments. ${ }^{31}$

28. VOC 1434, ff. 259-265; VOC 1593, ff. 589-611; VOC 2375, ff. 343-344; VOC 9030, ff. 92-107; VOC 2758, f. 128; VOC 2987, ff. 207-215; 's Jacob ed., De Nederlanders in Kerala, LII, and LIV n. 189; Idem, The rajas of Cochin, 36; Van Goor, De Nederlandse koloniën, 114; Marianne Wolff, "Cochin: Een mestiese samenleving in India”. Unpublished M.A. thesis (Leiden: Rijksuniversiteit Leiden, 1992), 37, 50, 71-72, and 72-73; Singh, Fort Cochin, 35, and 177; Jacobs, Koopman in Azië, 62-63; Van Welie, "Patterns", 214; Vink, "The Dutch East Indies", 192-193; Idem, "'The world's oldest trade"”, 148.

29. Jacobs, Koopman in Azië, 75-76; Gaastra, The Dutch East India Company, 50, 59, 70, 75, and 77.

30. Sanjay Subrahmanyam, The political economy of commerce: Southern India, 1500-1650 (Cambridge: Cambridge University Press, 1990), 23-24; Om Prakash, European commercial expansion in early modern Asia (Aldershot and Brookfield: Variorum, 1997), 57. For a 1665 description of Pulicat: VOC 1252, f. 795.

31. Vink, Encounters on the Opposite Coast, 452-453. Moreover, there were 32 indigenous vessels based in the 'outer city' at the time. See: VOC 1299, f. 135r. 
In 1781, during the Fourth Anglo-Dutch War, the number of besieged in Nagapatnam reportedly amounted to 8,000. Most likely, in view of its greater importance and scale, the town and its immediate Umland may have housed some 10,000 inhabitants. ${ }^{32}$

\section{The 'Central Zone': Malacca and Java (Batavia, Bantam, Cheribon, and the Pasisir)}

From its nadir of 2,700 in 1641 (reportedly down from 20,000) due to casualties incurred during the Dutch siege and mass flight and deportation in the immediate aftermath of conquest, the population of Malacca and its surroundings quickly rebounded from 3,280 in 1662 , and 4,486 in 1680 , to c. 6,000 in 1707 . Further limited expansion $(7,073$ in 1719) was interrupted in the mid-eighteenth century (10,849 in 1743 , and possibly 9,635 in 1750 and 7,216 in 1766), followed by rapid growth to 14,000 by the late eighteenth century (1796) due to the combined stimulus of English country traders and Chinese demand. As elsewhere, Malacca had a stagnant, and after 1750, decreasing pool of (Indo-)Europeans (from 2,339 or 24.28 percent in 1750 to 1,667 or 8.48 per cent in 1817), an initially growing, but after 1750 declining Chinese population (2,161 or 22.43 percent in 1750; 1,006 or 5.12 percent in 1817), and after 1750 rapidly increasing numbers of local Malay population, most likely representing an influx of agriculturalists (3,615 or 37.52 percent in 1750 to 13,988 or 79.20 percent in 1817). All these later numbers, unfortunately, include the slaves in the employ of their respective owner. In the seventeenth century, Malacca was a true slave society with slaves accounting for 35.20 percent of the total population (1,780 out of $5,057)$ in $1678,25.28$ percent $(1,134$ out of 4,486$)$ in 1680 , and 40.07 percent $(1,853$ out of 4,624) in 1682. Their relative share declined significantly afterwards with the massive inflow of local Malays: in 1743, the 1,402 slaves made up 'only' 12.02 per cent of Malacca's population of 10,849 , while in 1824 , shortly before the Dutch handover of the city to the English, the 1,314 slaves accounted for 11.75 percent of the population of $11,180 .^{33}$

The town of Melaka covered the town center (the Dutch fort of Melaka, the erstwhile Portuguese castle, on the southeastern bank of the river and the town) and the suburbs of Tengkera, Bandarhilir, Bungaraya, and Bukit China. The town and its surroundings were indistinguishable and used interchangeably with the total territory controlled by the Company in the VOC correspondence. The population of the town of Malacca is

\footnotetext{
32. F.R. Hemingway, Madras district gazetteers: Tanjore (Madras: Government Press, 1915), 244.

33. VOC 1157, ff. 533r-v; VOC 1214, f. 133v; VOC 1240, ff. 1438r, and 1441r-v; VOC 1332, ff. 561-563; VOC 1361, ff. 72-73; VOC 1452, ff. 1013-1014; VOC 1453, ff. 419-420; VOC 8632, f. 171; Van Dam, Beschryvinge, 2.1, 332, and 334. See also: M.J. Bremer, "Report of Governor Balthasar Bort on Malacca, 1678", Journal of the Malaysian Branch of the Royal Asiatic Society 5, 1 (1927), 1-234; Thomas Braddell, Statistics of the British Possessions in the Straits of Malacca (Penang: Pinang Gazette Printing Office, 1861), 3; Jacobs, Koopman in Azië, 154; Nordin Hussin, Trade and society in the Straits of Melaka: Dutch Melaka and English Penang, 1780-1830 (Copenhagen: NIAS Press, 2007), 163-166, 168, 171, 172, and 175; Kernail Singh Sandhu and Paul Wheatley ed., Melaka: The transformation of a Malay capital, c. 1400-1980 (New York: Oxford University Press, 1983), I, 197, and 207; II, 98, and 188-189; Vink, "The Dutch East Indies", 192-193; Idem, "The world's oldest trade", 148; Welie, "Patterns", 214. Hussin questions the reliability of the figures for 1750 and 1766 provided by Thomas Braddell, the first Attorney General of the Straits Settlements in 1861. See: Sandhu and Wheatley ed., Melaka, II, 188; Hussin, Trade and society, 165-166.
} 
therefore identical to the number of Dutch subjects.

The VOC 'comptoirs' on the island of Java eventually came to consist of Batavia (including the Ommelanden and the Preanger region), Bantam (Banten), Cheribon (Cirebon), and the Northeast coast of Java (Pasisir). The numbers for Batavia intramuros within the city's walls are discussed below. The first incomplete data regarding the number of VOC subjects for Batavia's Ommelanden are from the 1670s (9,311 for 1673; 13,593 for 1679 ) when the area had not yet been fully pacified. Numbers increased rapidly with the opening up of the region in the 1680 s, from 45,550 in 1689 , and 49,688 in 1699 , to 78,957 by 1729 . The subsequent slump in the sugar trade starting in the 1730 s combined with the Chinese Massacre of 1740 and Chinese War (1741-1743) caused a temporary decline (68,229 in 1739). However, by 1749 numbers had rebounded to 77,015. Expansion resumed until 1779 when the population totaled 161,215 people, followed by a decline to 143,339 in 1789. The number of Europeans and mestizos residing in the Ommelanden were miniscule and remained stagnant around 600-800 throughout the period. The real growth was caused by the increased numbers of Javanese and Balinese from 15,649 (31.49 percent) in 1699 to 61,970 (38.44 percent) in 1779 , and Chinese from 4,395 (8.85 percent) in 1699 to 32,626 (22.76 percent) in 1789 , though both stagnated for obvious reasons between 1739 and 1749. The number of slaves initially remained stable $(12,000-15,000)$ between 1689 and 1749, though grew slightly between 1759 (17,111 or 15.4 percent) and 1769 (21,635 or 18.83 percent), to peak at 34,018 (21.1 percent) in 1779 and 32,906 (22.96 percent) in $1789 .{ }^{34}$

For the Preanger region, a 1686 VOC report mentions 508 negorijen or settlements, while Jacob Cornelis Matthieu Radermacher and Willem van Hogendorp, two leading Company officials and co-founders of the Batavian Society of the Arts and Sciences at Batavia, mention 15,724 houses and 5,103 budjangs (unmarried men, servants, laborers or coolies) with a total population of 99,447 around 1775. In 1795 Commissioner-General Sebastiaan Cornelis Nederburgh put the combined population of the regencies of Jacarta and Priangan at 206,494. In 1815, Raffles held the population of the Preanger regencies at $243,628 .{ }^{35}$ In his study on the forced coffee cultivation in the Preanger region, Jan

\footnotetext{
34. VOC 1315, f. 502; VOC 1489, f. 205; Generale missiven, IV, 676-677; Raben, "Batavia en Colombo", 89, and 306332; Leonard Blussé, "An insane administration and an unsanitary town: The Dutch East India Company and Batavia (1619-1799)", in Colonial cities: Essays on urbanism in a colonial context, ed. Robert Ross and Gerard Telkamp (Dordrecht: Foris, 1985), 65-85; Hendrik Niemeijer, "Calvinisme en koloniale stadscultuur: Batavia, 1619-1725". Unpublished Ph.D. Thesis. (Amsterdam: Vrije Universiteit, 1997), 26; Van Welie, "Patterns", 214; Jacobs, Koopman in Azië, 175; Van Goor, De Nederlandse Koloniën, 110; Susan Abeyasekere, Jakarta: A history (Oxford: Oxford University Press, 1987), 41; Jaap Bruijn, Femme Gaastra, and Ivo Schöffer ed., Dutch-Asiatic shipping in the 17th and 18th centuries (The Hague: Nijhoff, 1987), I, 124.

35. Jacob Radermacher and Willem van Hogendorp, "Korte schets van de bezittingen der Nederlandsche Oost-Indische Maatschappye benevens eene beschrijving van het koninkrijk Jaccatra en de stad Batavia", Verhandelingen van het Bataviaasch Genootschap van Kunsten en Wetenschappen. 3rd edn. (1825), I, 8; Idem, "Bijvoegsels tot de beschrijving der Sundasche Eilanden: Java, Borneo en Sumatra", Verhandelingen van het Bataviaasch Genootschap van Kunsten en Wetenschappen. 2nd edn. (1824), III, 272-273; "Bevolking van Java en Madura", Tijdschrift voor Neêrlands Indië 2 (1839), I, 160; Thomas S. Raffles, The history of Java. 1st edn. (London: John Murray, 1817), I, 63; II, 241-291.
} 
Breman argues that all statistical surveys taken during the Company period suffer from 'sufficient knowledge, reach, and meticulousness to even approximate the true size of the population, though he does list 146,700 for $1808 .{ }^{36}$ The uneven but lightly populated frontier zone reported only limited demographic growth due to colonial tribute levies and exactions, high mortality rates caused by epidemics, and systematic underreporting by indigenous headmen. ${ }^{37}$

For the Northeast Coast of Java, Bantam, and Cheribon we have a number of contemporary reports dating back to the period 1775-1815, a time of rapid population growth due to the end of warfare (the Pax Neerlandica) and the opening up of the region's private trade by the VOC government in Batavia. Radermacher and Van Hogendorp estimated that c. 1775 the Company directly controlled 69,000 cacahs or wet-rice farms, of 6 members each, with a population of 414,000 along the Pasisir, with Java's total population said to be 2,029,915..$^{38}$ According to the 'first somewhat reliable census of population' of $1796^{39}$ by European and Javanese commissioners instigated by Governor Pieter Gerardus van Overstraten of Java's Northeast Coast, the region housed 8,585 negorijen or settlements and 951,413 inhabitants, while the Oosthoek or Eastern Salient of Java (including the island of Madura) held 5,322 negorijen and 544,495 inhabitants for a total of 1,495,908 indigenes. According to the Dutch governor, the number was in fact a low estimate: not only had a few regencies not been included in the census, but it also left out Europeans, Chinese, 'nations from the opposite coast' (Balinese etc.), and Javanese at sea. Using these exact same numbers $(1,495,908)$, Commissioner-General Nederburgh in 1795 estimated the total Javanese population to be over 3.5 million. ${ }^{40}$ Another detailed survey of the Northeast Coast in 1802 conducted under the auspices of Governor Nicolaas Engelhard counted 1,879,559 residents, while Governor-General Herman Daendels held the number of inhabitants of the Northeast Coast (including Madura and the Eastern Salient) around 1807 to be $1,600,000 .{ }^{41}$ In 1815, Lieutenant-Governor Thomas Stamford Raffles of British Java put the population of the residencies of the Northeast Coast (including Madura) at $1,897,776$, while he set the total population of Java at 4,615,270. Almost the same figure $(4,527,767)$ is given by Boomgaard (1989), though, pace Bram Peper (1970), Van Zanden

\footnotetext{
36. Jan Breman, Koloniaal profijt van onvrije arbeid: Het Preanger stelsel van gedwongen koffieteelt op Java, 1720-1870 (Amsterdam: Amsterdam University Press, 2010), 35, 98, and 256.

37. Idem, 98-99.

38. Radermacher and Van Hogendorp, "Korte schets", 8; Idem, "Bijvoegsels", 274.

39. Ann Kumar, Java and modern Europe: Ambiguous encounters (Richmond: Curzon Press, 1997), 205. Ricklefs, on the other hand, has limited confidence in the estimates. See: Merle C. Ricklefs, "Some statistical evidence on Javanese social, economic and demographic history in the later seventeenth and eighteenth centuries", Modern Asian Studies 20, 1 (1986), 30 .

40. Johan K.J. de Jonge ed.,, De opkomst van het Nederlandsch gezag over Java (The Hague: Nijhoff, 1884), XII, 406407; Pieter J. Veth, Johannes F. Snelleman, and Jan F. Niermeyer, Java: Geographisch, ethnologisch, historisch. 2nd edn. (Haarlem: De Erven F. Bohn, 1896), I, 229-230; Pieter Bleeker, Nieuwe bijdragen tot de kennis der bevolkingstatistiek van Java (The Hague: Nijhoff, 1870), 7; "Bevolking van Java en Madoera”, Tijdschrift voor Neêrland's Indië 2 (1839), I, 154170, esp. 160. 41. Veth, Snelleman, and Niermeyer, Java, 8.
} 
and Marks (2012) put the population of Java at 7.5 million in 1800 and 10 million in 1820.42

The number of subjects at the two other Javanese 'comptoirs' are much smaller. Radermacher and Van Hogendorp put the population of Bantam c. 1775 at 90,000. ${ }^{43}$ Excluding the interior, a contemporary 1787 incomplete estimate by the local VOC merchant and second-in-command Jan de Rovere van Breugel puts the total population in Bantam's coastal region at 45,000, living in 84 negorijen. ${ }^{44}$ In 1795, CommissionerGeneral Nederburgh simply took over the numbers provided by Radermacher and Hogendorp (90,000). Daendels around 1807 came to 80,000. While these numbers are fairly consistent, Raffles in 1815 arrived at no less than 231,604 for the Bantam residency. ${ }^{45}$ Ever the reluctant imperialist, before Bantam's further reduction in status in 1755/1756, the VOC, apart from its own local personnel, only counted a tiny segment of Bantam's inhabitants as its subjects ranging from 420 (plus 390 VOC personnel) in 1689 to 1,0001,500 in the period between 1704 and 1728. In the virtual absence of Europeans, the majority of the 'foreign subjects' were Chinese (900-1,100) supplemented by a smattering of 'Moors and Gentiles', Mardijkers, and Asian freeburghers overwhelmingly residing in the city of Bantam. ${ }^{46}$ The population of Cheribon was estimated at 305,600 in 1705, but in 1754, c. 1775 (Radermacher and Van Hogendorp), and 1795 (Nederburgh) at only 90,000. Once again, Raffles in 1815 is at variance with the earlier numbers, putting the inhabitants at $216,001 .^{47}$

Dutch Java's (and the Dutch Indian Ocean World's) primate city was Batavia. The secondary urban centers of Bantam, Cheribon, and the Pasisir towns followed at considerable distance. Batavia had a checkered existence, changing from 'Queen of the East' in the seventeenth century to 'Graveyard of the Europeans' in the eighteenth century.

42. Raffles, The history of Java, I, 63; II, 241-291; Peter Boomgaard, Children of the colonial state: Population growth and economic development in Java, 1795-1880 (Amsterdam: Free University Press, 1989), 154; Bram Peper, "The population of Java in the 19th century: A new interpretation", Population Studies 24, 1 (1970), 71-84; Jan Luiten van Zanden and Daan Marks, An economic history of Indonesia, 1800-2010 (London: Routledge, 2012), 36, 74, and 113. Bleeker puts the population of Java for 1802 at 3,647,167: Veth, Snelleman, and Niermeyer, Java, 8, and 10.

43. Radermacher and Van Hogendorp, "Korte schets", I, 8; Idem, "Bijvoegsels", III, 274; "Bevolking van Java en Madura", I, 160.

44. Jan de Rovere van Breugel, "Beschrijving van Bantam en de Lampongs", Bijdragen tot de Taal-, Land-en Volkenkunde van Nederlandsch-Indië, New Series, 1 (1856), 309-362, esp. 320; Idem, "Bedenkingen over den staat van Bantam", 106-170, and 309-357; Kumar, Java and modern Europe, 259-260; Ota Atsushi, Changes of regime and social dynamics in West Java: Society, state and the outer world of Banten, 1750-1830 (Leiden and Boston: Brill, 2006), 18-19. 45. Raffles, The history of Java, I, 63; II, 241-291. The number is used by Bleeker, Nieuwe bijdragen, 14; Veth, Snelleman, and Niermeyer Java, 8, and 10.

46. For numbers: Generale missiven, V, 344; VI, 324-325, 380, 460-461, 510, 571, and 638-639; VII, 129, and 448; VIII, 29 , and 219.

47. Radermacher and Van Hogendorp, "Korte schets", 8; Idem, "Bijvoegsels", 274; "Bevolking van Java en Madura", 160; Raffles, The history of Java, I, 63; II, 241-291; Veth, Snelleman, and Niermeyer, Java, 8, and 10; Kumar, Java and modern Europe, 231. Bleeker puts the number at 233,956 for 1815. See: Bleeker, Nieuwe bijdragen, 56. Hoadley estimates Cheribon's population around 1700 at 9,000 somah (one household of 6 persons). See: Mason Hoadley, "Slavery, bondage, and dependency in pre-colonial Java: The Cirebon-Priangan region, 1700", in Slavery, bondage and dependency in Southeast Asia, ed. Anthony Reid (New York: St. Martin's Press, 1983), 113, and 115. 
As Asian headquarters and central rendezvous of the VOC, Batavia's population initially witnessed an explosive growth, especially during the first decades after its founding. Numbers increased from a mere 350 in $1618,8,000$ in 1632, c. 15,000-16,000 in 1656, and 17,740 in 1673 , to 21,911 by 1699 . Between 1700 and 1730 the population within the walls stagnated around 20,000-23,000. This stagnation was followed by a steep decline caused by environmental devastation in the Ommelanden, the expansion of coastal saltwater fishponds (tumbaks) north of the city conducive to waterborne diseases (typhus, malaria, dysentery, beriberi), and the resulting flight of higher-ranking VOC officials to the countryside - a pattern common in the Dutch Indian Ocean World in the second half of the eighteenth century. ${ }^{48}$

Slaves were the largest group (after 1670), consistently forming more than half of the population: 9,938 out of 17,740 (56.02 percent) in 1673, and 4,339 out of 8,497 (51.07 percent) in 1797. A pivotal role as 'co-colonizers' was also played by the local 'Overseas Chinese' (huaqiao). Batavia (and several other settlements in the Dutch Indian Ocean World) at least to some extent can be considered 'Chinese colonial towns'. This middling group, however, suffered a mortal blow during the Chinese Massacre of 1740 from which it, and the city, never fully recovered with numbers plunging from 4,199 out of 18,302 (22.94 percent) in 1739 , to 1,590 out of 14,141 (11.24 percent) in 1749, and 1,978 out of 8,497 (23.28 percent) in 1797. As elsewhere, Europeans and mestizos were a stagnant or declining group. Europeans accounted for 1,783 (8.14 percent) in 1699, 1,276 (6.97 percent) in $1739,1,541$ (10.90 percent in 1749), and 478 (5.63 percent) in 1797. Mestizos alternatively made up 670 (3.06 percent) in 1699, 421 (2.30 percent) in 1739, 677 (4.79 percent) in 1749, and 307 (3.61 percent) in $1797 .{ }^{49}$

Bantam (Kotah Banten) under Dutch rule became a far less hospitable and habitable city, outflanked and overshadowed by its powerful neighbor to the east, Batavia. Following the expulsion of foreign merchants in 1684, the population of the city of Bantam declined from c. $12,000-15,000$ in the 1670s, to (according to Director-General Jacob Mossel)

48. After 1730, mortality rates at Batavia increased to one-fifth, at times even one-third, of all new arrivals from Europe within six months, compared to only 5-10 per cent in the VOC's Indian 'comptoirs', such as Ceylon and Bengal. Between 1733 and 1795, at least 85,000 Company servants died in the Inner Hospital at Batavia, 'by far the most unhealthy settlement of the VOC in Asia', followed closely by Java's Northeast Coast, Bantam, and Banda. Peter van der Brug, Malaria en malaise: De VOC in Batavia in de achttiende eeuw (Amsterdam: De Bataafsche Leeuw, 1994), 29, 200, and 204. 49. Hendrik Niemeijer, Batavia: Een koloniale samenleving in de 17de eeuw (Amsterdam: Balans, 2005), 26, and 37; Kees Grijns and Peter Nas ed., Jakarta-Batavia: Socio-cultural essays (Leiden: KITLV Press, 2000); Abeyasekere, Jakarta, 19-20; Leonard Blussé, Strange Company: Chinese settlers, mestizo women and the Dutch in VOC Batavia (Dordrecht: Foris Publications, 1986); Jean Gelman Taylor, The social world of Batavia: European and Eurasian in Dutch Asia (Madison and London: University of Wisconsin Press, 1983), 4; Frederik de Haan, Oud-Batavia. 2nd edn. (Bandung: A.C. Nix and Co., 1935), II, 348; Idem, Priangan: De Preanger-regentschappen onder het Nederlandsch bestuur tot 1811. 4 vols. (Batavia: Bataviaasch Genootschap van Kunsten en Wetenschappen, 1910-1912); Raben, "Batavia en Colombo", 306-332; Blussé, "An insane administration"; Gerrit Knaap, Shallow waters, rising tide: Shipping and trade in Java around 1775 (Leiden: KITLV Press, 1996), 25; Jacobs, Koopman in Azië, 175; Van Goor, De Nederlandse Koloniën, 110; Vink, "Dutch East Indies", 192-193; Idem, “'The world's oldest trade", 148; Van Welie, "Patterns", 214. 
about 10,000 by 1747 , and 5,235 in $1815 . .^{50}$

Semarang and Surabaya were the largest among the Pasisir towns. Semarang, the capital of Java's Northeast Coast after 1708, had a population of c. 10,000-20,000 in the 1770 s and approximately 22,000 in 1812, while Raffles put the number at c. 25,000 in $1815 .^{51}$ The population of Surabaya similarly may have amounted to something between 10,000 and 20,000 in the 1770s, and perhaps 20,000 around 1800, whereas the number of the other Pasisir towns-Tegal, Pekalongan, Demak, Japara, Joana (Juwana), Rembang, and Grise - must have been below 10,000.52

\section{The 'Eastern Districts’: Banda, Ambon, Ternate, and Makassar}

The establishment of global monopolies in nutmeg and mace (1622) and cloves $(1662 / 1669)$ involved the VOC in a series of bloody conflicts in eastern Indonesia and led to the establishment of four territorial 'comptoirs' with the ranking of government: Banda, Ambon, Ternate, and Makassar. The spice monopoly remained unchallenged until the successful rebellion led by Prince Nuku of Tidore in conjunction with the English intrusion in the 'Eastern Seas' after 1780. ${ }^{53}$

Initial depopulation of the islands' original inhabitants was followed by their gradual, if only partial, repopulation with European gardeners and chattel laborers. Despite endemic low-level slave raiding, continuous maroonage, repeated earthquakes and eruptions of the volcano Gunung Api (no less than 14 times between 1600 and 1800), ${ }^{54}$ and the recurrence of virulent epidemics, ${ }^{55}$ the number of Dutch subjects initially rose from 1,800 in 1621 to $4,000-5,000$ by the 1650 s. This figure stabilized around 6,000 8,000 from the 1670 s $(1671: 6,760 ; 1723: 7,413)$ into the late 1780 s $(6,782$ in 1787$)$,

50. De Jonge, De Opkomst van het Nederlandsch gezag, X, 118-119; Johan Talens, Een feodale samenleving in koloniaal vaarwater: Staatsvorming, kolonial expansie en economische onderontwikkeling in Banten, West Java (1600-1750) (Hilversum: Verloren, 1999), 46-51; Atsushi, Changes of regime, 18-19; Jacobs, Koopman in Azië, 54. Ulbe Bosma puts Bantam's population around 1650 to be 5,000-10,000. See: Ulbe Bosma, "Labour relations in Java, 1650, 1800, 1900", Global Collaboratory on the History of Labour Relations 1500-2000 (2011), https://collab.iisg.nl/c/document_library/ get_file?p_1_id=273223\&folderId=283125\&name=DLFE-77732.pdf

51. Nagtegaal, Riding the Dutch tiger, 93; Knaap, Shallow waters, 25; Idem, "Semarang: A colonial provincial capital and port city in Java, circa 1775", in Commodities, ports and Asian maritime trade, c. 1750-1950, ed. Anthony Webster, Ulbe Bosma and Jaime de Melo (London: Palgrave Macmillan, 2015), 85; Denys Lombard, "Une description de la ville de Semarang vers 1812 (d'après un manuscript de l'India Office)", Archipel 37 (1989), 264; Raffles, The history of Java, I, 63; II, 241-291; Van Zanden and Marks, An economic history of Indonesia, 36. Bosma, pace Nagtegaal, puts the number for 1650 at 10,000-20,000 and c. 25,000 for 1800. See: "Labour relations in Java".

52. Knaap, Shallow waters, 25; Bosma, "Labour relations in Java". See also: Gerrit Knaap, "Maritime trade in small-town Java around 1775: The cases of Tegal and Pekalongan", in Linking destinies: Trade, towns and kin in Asian history, ed. Peter Boomgaard, Dick Kooiman, and Henk Schulte Noordholt (Leiden: KITLV Press, 2008), 81-98; Idem, "Semarang", 79-94. 53. Muridan Widjojo, The revolt of Prince Nuku: Cross-cultural alliance making in Maluku, 1780-1810 (Leiden: Brill, 2008).

54. Located on the world's seismically most active region, the so-called 'Ring of Fire', the volcano erupted in 1609, 1614 1615, 1632, 1635, 1683, 1690, 1712, 1722, 1749, 1762, 1765, 1773, 1775, and 1778.

55. Between 1638 and 1712 alone, there were eight reported outbreaks of epidemics in 1638, 1656, 1678-1679, 1693, 1702, 1705, 1709, and 1712 . 
with a decline afterwards to 6,020 in 1790 and 5,773 in 1792. Slavery and the forced cultivation of nutmeg and mace were not abolished in the Dutch East Indies until 1860 and 1864, respectively. Not surprisingly, slaves constituted the majority of the population throughout the period, accounting for 3,731 out of 6,375 (58.53 percent) in 1687 and 4,902 out of 6,643 (73.79 percent) a hundred years later in 1787. While Europeans and mestizos combined accounted for 1,111 (17.43 percent) in 1687, Europeans in 1787 had dwindled to a mere 153 (2.30 percent), whereas the number of mestizos was 726 (10.93 percent). Banda's Chinese community was miniscule, making up only 86 (1.29 percent) in $1787 . .^{56}$

The town of Neira or Bandaneira, the seat of the VOC governor of Banda, was a small urban settlement enveloped around the 'twin fortresses' of Fort Nassau and nearby Fort Belgica. Located on the only island with enough flat space to allow for a larger settlement, it may have housed almost half of the population of the area, probably less than 3,000 in the eighteenth century and even less before 1670. In 1854, the island of Neira reportedly had 3,201 residents, including 304 Europeans and their descendants, 614 Muslims, 514 indigenous Christians, 143 Chinese, 170 Timorese and Tenimberese, 73 free indigenous laborers, 174 bonded servants (perkhorige lieden), 513 private slaves, and 660 exiles. By the 1890s, in the wake of the abolition of slavery and forced cultivation, Banda had become, in the words of one observer, effectively a 'dead city.' ${ }^{57}$

Following the conquest of Banda and the acquisition of the nutmeg and mace monopoly in 1622, it took the VOC another forty years before it succeeded in acquiring the same in cloves. The number of VOC subjects in Ambon is based on the Company's annual 'soul counts' (zielsbeschrijvingen). Despite various reservations about their reliability, they contain 'unique data' about the Ambonese population in the seventeenth and eighteenth centuries. ${ }^{58}$ The number of VOC subjects in Ambon increased commensurate with the Company's territorial expansion, from $35,000-40,000$ in the 1660 s to reach a ceiling of $70,000-80,000$ by 1700 . The increasingly ruthless wars (until 1656/1658) and possibly related migrations, repeated waves of epidemics (1671/1672, 1677/1678, 1682/1684, and 1689/1691), natural disasters (most notably the 1674 earthquake centered at Hitu followed by a massive tsunami), and low-level endemic raiding, 'merely' acted as growth

\footnotetext{
56. VOC 8031, ff. 388v-389r; VOC 7943, ff. 274v-275r; VOC 8033, ff. 339v-340r; VOC 7947, ff. 292v-293r; Generale missiven, I, 148, 223-224, 361, and 615-616; II, 496, 596, and 748; III, 751, and 838; IV, 130, 188, 242, 433, 654-655, 713, and 793-794; V, 106-107, 203-204, 300-301, 392, 447, 517, 608, 610, 657, 674, 676, 749, 782, and 837; VI, 19, 67, 118, 178, 190, 293, 347, and 847; VII, 355, 415, 554, 611, and 710-711; Van Dam, Beschryvinge, Part 2.1, 159, 177, 195, and 199-200; II, 246 et seq..; Willard Hanna, Indonesian Banda: Colonialism and its aftermath in the nutmeg islands (Philadelphia: Institute for the Study of Human Issues, Inc., 1978), 66; Van Welie, "Patterns", 214, and 223.

57. Susie Protschky, Images of the tropics: Environment and visual culture in colonial Indonesia (Leiden: KITLV Press, 2011), 41; Pieter Veth ed., Aardrijkskundig en statistisch woordenboek van Nederlandsch Indië (Amsterdam: P.N. van Kampen, 1869), II, 552.

58. Gerrit Knaap, Kruidnagelen en Christenen: De Verenigde Oostindische Compagnie en de bevolking van Ambon 16561696 (Providence and Dordrecht: Foris, 1987), 99, 103-104, 107, 114-122, and 127-128; Gaastra, The Dutch East India Company, 87, and 97.
} 
retardants. Population numbers were to stabilize until the late 1730 s $(79,749$ in 1739 ; 70,679 in 1740) and then, reflecting Prince Nuku's successful rebellion, to drop sharply to 54,641 in $1780,45,218$ in 1785 , and 53,567 in 1790. Similar to other Dutch 'territorial comptoirs', the European segment of the population declined sharply from 928 or 1.31 percent in 1740, to 319 or 0.58 percent in 1780. As in Banda, the Chinese presence was miniscule (450 or 0.64 percent in $1740 ; 387$ or 0.71 percent in 1780). Christian, Muslim, and 'Heathen' Ambonese formed the great majority of the subject population. ${ }^{59}$

At its height, the population of the central place of Kotah Ambon ranged between $4,000-6,000$, reaching 4,089 in $1673,4,639$ in $1683,5,487$ in 1694 , and 5,254 in 1732 . The town then declined in prosperity and population, only to recover in the late eighteenth century with the end of the VOC's restrictive spice monopoly. In the nineteenth century, the city (including suburbs) experienced renewed growth and increased in numbers to 11,814 (1833), 9,274 (1839), and 10,500 (1855). In 1694, the 2,870 slaves of the town made up more than half (52.31 percent) of the population..$^{60}$

In order to secure the monopoly positions of Ambon and Banda, the VOC also established a large number of forts and other posts in the northern Moluccas (Maluku) with its wild clove and nutmeg trees. The population of Ternate witnessed a sharp decline in population in the seventeenth century due to wars, most notably during the reigns of Sultan Mandar Syah (1651-1656) and Sultan Amsterdam or Sibori (1681-1683), and heavy corvéé labor demands. In the aftermath of the 1683 treaty, including the recognition of the overlordship of 'Father Kompenie', the number of VOC householder-subjects recovered from 1,438 (including Company personnel) in 1686, to 2,661 in 1700. It then stabilized in the 1730 s $(2,779$ in $1741 ; 2,511$ in $1768 ; 2,608$ in 1773$)$, until the rebellion led by Prince Nuku of Tidore after 1780. A (possibly incomplete) list from 1779 gives only 1,603 residents. In 1819, there were 2,620 Dutch government subjects and 3,983 subjects of the sultan. ${ }^{61}$

59. VOC 7914, ff. 686v-687r; VOC 7949, ff. 242v-243r; VOC 7940, ff. 18v-19r; VOC 7946, ff. 22v-23r; Generale missiven, III, 601, 835, 896, and 927; V, 28, 104, 202, 299, 390, 444-445, 516-517, 605-606, 672-673, 746, 781, and 835-836; VI, 18, 67, and 117; VII, 661; Maarten Vanhaverbeke, "De VOC op Ambon in 1732: Een socio-economische analyse". Unpublished M.A. thesis (Gent: Universiteit van Gent, 2006-2007), 100, and 104, https://lib.ugent.be/fulltxt/ RUG01/001/311/478/RUG01-001311478_2010_0001_AC.pdf; Hanneke Lommerse, "Population figures", Dutch colonialism, ed. Oostindië, 318. In 1819, the population of Ambon was 59,316. See: "De Moluksche eilanden", Tijdschrift voor Nederlandsch-Indië 18, 1 (1856), 240-241.

60. Knaap, Kruidnagelen en Christenen, 101, and 132; Gerrit Knaap, "A city of migrants: Kota Ambon at the end of the seventeenth century", Indonesia 51 (1991), 120, and 124; Vink, "Dutch slavery and slave trade", 148; Christiaan de Jong, De Protestantse kerk in de Midden-Molukken, 1803-1900 (Zoetermeer: Boekencentrum, 2004), I, 339-340; Idem, "The Life and work of Bernhard Nikolas Johann Roskott on the island of Ambon, Indonesia", https://www.researchgate.net/ publication/259885455_The_Life_and_Work_of_Bernhard_Nikolas_Johann_Roskott_1811-1873_on_the_Island_of_Ambon_Indonesia, 2; Van Welie, "Patterns", 214; Vanhaverbeke, "De VOC op Ambon", 100-101; Veth ed., Aardrijkskundig en statistisch woordenboek, 24.

61. VOC 8136, f. 39r; VOC 8138, f. 207r; VOC 8139, f. 220v; VOC 8140, ff. 455-463; Generale missiven, IV, 269; V, 33, 306, 450, 718, 750, 783, and 837; VI, 21, 68, 119, 180, 195, 265, 295, and 350; X, 418, and 768; "De Moluksche eilanden", Tijdschrift voor Nederlandsch-Indië 18, 1 (1856), 242; Christiaan van Fraassen, "Ternate, de Molukken en de Indonesische Archipel: Van soa-organisatie en vierdeling". Unpublished Ph.D. Thesis. (Leiden: Rijksuniversiteit Leiden, 1987), I, 66-78, and 85. 
The number of VOC subjects was largely identical with the population of the town of Ternate and its suburbs. Built in 1607, Fort Orange, nowadays part of Kotah Ternate, was located on the southeast of the island. Serving as the seat of the VOC governor of Ternate (the Moluccas), the fort became the nucleus of the most important urban center on the island. It housed the majority of VOC personnel, while most of the European and indigenous citizenry and subjects (indigenous Christians, Chinese, and Makassarese), resided in the neighboring Kampung Serani, Kampung Cina, and Kampung Makasar, respectively. Alfurese, $\mathrm{Bac}(\mathrm{h})$ anese, and other local inhabitants, originally counted as subjects, were later excluded from VOC censuses. With a shrinking number of Europeans, the town was dominated by the slave populations, while the Chinese formed a small minority. In 1682, slaves made up 591 out of 1,855 (31.86 percent) of Ternate's population against 461 out of 1,269 (36.33 percent) of that of Fort Orange. Dutch accounted for 680 (36.66 percent) in Ternate and 407 (32.07 percent) in Fort Orange itself. Mestizos made up 278 (14.99 percent) in Ternate and 169 (13.32 percent) in Fort Orange. Chinese, Makassarese, and 'Natives' numbered 306 (16.50 percent) in Ternate and 232 (18.28 percent) in Fort Orange. Almost a century later, in 1773, slaves accounted for 1,138 out of 2,608 (43.63 percent) of the town's population, the families of Company servants for 314 (12.04 percent), (indigenous) burghers for 165 (6.33 percent), and Christian widows for 96 (3.68 percent), while the total number of Chinese, Makassarese, and free servants combined amounted to 895 (34.32) percent). ${ }^{62}$

Apart from the conquest of the spice producing islands in eastern Indonesia themselves, the effective establishment of a monopoly also required the subjugation of nearby trading emporia such as the sultanate of Gowa-Tallo (Goa-Tallo) and its free port ('smuggle haven' in the eyes of the VOC) of Makassar, the 'key to the Moluccas'. There are no actual complete censuses available for the period of VOC rule in Makassar. The lists of subjects available are likely underreporting the actual numbers as they are either based on Company estimates, or information provided by indigenous authorities with no particular interest in making the number of their subjects seem large and powerful. Guesstimates of the number of subjects increased from 34,490 in 1699, 41,340 in 1720, and 40,695 in 1740, to 54,041 in 1760. Similar to the other VOC 'comptoirs' in the 'Eastern Districts', the population then declined to 41,261 in $1770 .{ }^{63}$

The nucleus of the urban settlement of Makassar consisted of Fort Rotterdam and the small town of Vlaardingen to the northeast. Despite temporary setbacks, including widespread fires in 1679, 1680, and 1791, and the general instability caused by Arung

62. VOC 8136, f. 39r; VOC 8138, f. 207r; VOC 8139, f. 220v; VOC 8140, ff. 455-463; VOC 8062, ff. 222v-223r; Generale missiven, V, 33; Van Fraassen, "Ternate", I, 85.

63. Generale missiven, V, 522, 684, 751, and 840; VI, 24, 73, 164, 195, 238-239, 298-299, 353-354, 485, 607, and 852; VII, 48, 139, 457, 522, 586, and 717-718; VIII, 13, 77, 134, and 197; IX, 151; X, 268, and 609; Jürgen Nagel, Der Schlüssel zu den Molukken: Makassar und die Handelsstrukturen des Malaiischen Archipels im 17. und 18. Jahrhundert (Hamburg: Kovac, 2003), I, 419-420, and 420 n. 1138. Nagel states that for 'the late seventeenth century', the VOC assumed there were 'about 26,000 subjects'. 
Singkang, the Arung Matoa ruler of the Bugi state of Wajo, between 1737 and 1754, the population steadily increased from 1,100 in the early 1680 s, and 2,000 in 1730 to 3,000 in 1780. The total population of the town agglomeration under immediate VOC control, including the neighboring Kampung Baru, Kampung Melayu, Kampung Bugis, and others, grew more modestly from 5,622 in 1701 to 7,641 in 1791. A major impetus for the town was the arrival of the Amoy junk to the port: intermittently between 1746 and 1769, after which annual visits occurred. These large vessels carried tobacco, tea, silk, pans, and linen in exchange for, first and foremost, trepang accompanied by small amounts of wax, birds' nests, tortoise shell, and seaweed (agar-agar). Makassar was a slave society with slaves accounting for 921 out of 1,384 (66.55 percent) of Fort Vlaardingen's population in 1676, and 2,913 out of 4,983 (58.46 percent) of the larger conurbation (probably excluding VOC personnel) in 1730. The Chinese formed a small community, at least in the seventeenth century, accounting for 124 (8.96 percent) in 1676, though their numbers must have increased in the eighteenth century. ${ }^{64}$

\section{Conclusion: Seismic Changes and Tidal Waves}

Measuring the Dutch littoral footprint and sizing up the Dutch activities on land is beset with several definitional and numerical problems. The numbers presented here are therefore 'soft' and suggestive rather than hard and conclusive. Though conforming by and large to the overall general tripartite periodization of Company history, many of its individual 'territorial comptoirs' and some of their demographic variables - the magnitude of the Dutch subject population in general, and the size and ethnic makeup of the main urban centers in particular- displayed distinct variations over time due to particular sets of local natural and manmade factors.

In De Nederlandse koloniën (1994), the Company historian Jur van Goor made a 'rough estimate' of the number of Company subjects in the second half of the eighteenth century and arrived at a total of 'more than half a million', including 60,000 on Ambon, 50,000 in South Sulawesi, over 100,000 in Batavia and surroundings, and 200,000-300,000 in Ceylon. Van Goor explicitly noted that these numbers did not take into account Coromandel and the Pasisir. Ten years later, in his Prelude to colonialism (2004), Van Goor came up with another 'survey' of Dutch settlements at the end of the eighteenth

64. Generale missiven, IV, 138, 272, and 337; V, 751; VI, 164; VII, 717-718; VIII, 13, 77, and 134; Van Goor, Nederlandse koloniën, 114; Heather Sutherland, "A Sino-Indonesian commodity chain: The trade in tortoiseshell in the late seventeenth and eighteenth centuries", in Chinese circulations: Capital, commodities, and networks in Southeast Asia, ed. Eric Tagliacozzo and Wen-chin Chang (Durham and London: Duke University Press, 2001), 185; Idem, "Ethnicity, wealth and power in colonial Makassar: A historiographical reconsideration", in The Indonesian city: Studies in urban development and planning, ed. Peter Nas (Dordrecht and Cinnaminson: Foris, 1986), 41-42; Idem, "Eastern emporium and company town", 115; Idem, "The Makassar Malays: Adaptation and identity, c. 1660-1790", in Contesting Malayness: Malay identity across boundaries, ed. Timothy Barnard (Singapore: Singapore University Press, 2004), 86; Gerrit Knaap and Heather Sutherland, Monsoon traders: Ships, skippers and commodities in eighteenth-century Makassar (Leiden: KITLV Press, 2005), 18. 
century and concluded that 'over 600,000' Asians were under the direct rule of the VOC, which, if not the Dutch Republic itself (1,850,000-1,950,000 in 1700; 2,100,000 in 1800), exceeded the population of several contemporary German states. ${ }^{65}$

On the basis of our littoral census (see: Table 1), the overall size of the VOC subject population increased fivefold from $453,000-503,000$ in the late seventeenth century to $2,445,000$ in the late eighteenth century, and, if we take the De Zwart's revisions of the VOC Ceylon's population seriously, possibly even sixfold to 2,902,000. Ceylon with its 250,000-300,000 accounted for the bulk share in the late seventeenth century with Ambon (70,000), Batavia and Ommelanden $(65,000)$, and Makassar $(30,000)$ as important secondary centers. In the late eighteenth century, Java's 'comptoirs' (most notably the Northeast Coast with 1,500,000, followed by Batavia and Ommelanden 159,000, Preanger 100,000, Cheribon 90,000, and Bantam 80,000) and Ceylon 350,000-817,000 formed the dual demographic heart of the body politic of the Dutch Indian Ocean World with the 'Eastern Districts' of Ambon (50,000) and Makassar $(40,000)$ once again featuring as important secondary appendages, and the Cape Colony $(25,000)$ as a new member on the scene. Anything but a paper tiger on Ceylon, island Southeast Asia, and South Africa, the Dutch Indian Ocean World was a mouse-deer (kanchil) compared with the massive populations of China (138 million in 1700; 300 million in 1800) and India (165 million in $1700 ; 200$ million in 1800) ${ }^{66}$

Without exception, all central places in the Dutch Indian Ocean World (see: Table 2) were true slave societies, in which slaves played an important part in both luxury and productive capacities, empowering particular groups of elites, deeply influencing cultural developments, and forming a high percentage of the total population. ${ }^{67}$ Some, most notably Batavia, Malacca, and Fort Zeelandia on Taiwan (the 'neglected Formosa'), have been called 'Chinese colonial towns' under Dutch protection. A synergetic product of 'co-colonization' where a Dutch military and administrative structure co-evolved with a Chinese agricultural and commercial colony of 'Overseas Chinese' (huaqiao), emerging out of close cooperation between the Company and Chines entrepreneurs. ${ }^{68}$ Though mixed populations (mestizos, castizos, etc.) remained more stable, the 'European' urban

\footnotetext{
65. Van Goor, Prelude to colonialism, 23; Idem, De Nederlandse koloniën, 135. For the population figures of the Dutch Republic: Johannes Alle Faber, "Population changes and economic development in the Netherlands: A historical survey", A.A.G. Bijdragen 12 (1965), 110; Jan de Vries and Ad van der Woude, The first modern economy: Success, failure, and perseverance of the Dutch economy, 1500-1815 (Cambridge and New York: Cambridge University Press, 1997), 49-50. 66. For a synthesis: Angus Maddison, The world economy: A millennial perspective (Paris: OECD, 2001), 112, 213, 232, 236-237, and 241; Idem, The world economy: Historical statistics (Paris: OECD, 2003), 256, and 259; Maddison Project Database 2018, https://www.rug.nl/ggdc/historicaldevelopment/maddison/releases/maddison-project-database-2018. 67. Matthias van Rossum, Kleurrijke tragiek: De geschiedenis van slavernij in Azië (Hilversum: Verloren, 2015); Richard B. Allen, European slave trading in the Indian Ocean, 1500-1800 (Athens: Ohio University Press, 2015); Vink, “'The world's oldest trade".

68. Tonio Andrade, How Taiwan became Chinese: Dutch, Spanish, and Han colonization in the seventeenth century (New York: Columbia University Press, 2008); Anthony Reid ed., Sojourners and settlers: Histories of Southeast Asia and the Chinese (Honolulu: University of Hawaii Press, 1996); Blussé, Strange Company; Tagliacozzo and Cheng ed., Chinese circulations.
} 
component, with the notable exception of Cape Town and the Cape Colony, dwindled over the course of the eighteenth century due to, among others, the VOC's restrictive commercial policies, and increased mortality rates, most notably in Batavia and other Indonesian 'comptoirs'. This decline was in turn accompanied with a flight to the suburbs and surrounding countryside by the higher-ranking VOC personnel in central places such as Batavia (after 1733), Colombo, Fort Cochin, and Malacca. While remaining outward-looking, internationally-oriented littoral societies, localization and creolization accompanied the process of territorialization with the concomitant influx and natural increase of indigenous agrarian populations profiting from the Pax Neerlandica. These groups included the Javanese and Balinese on Java, Tamils and Sinhalese on Ceylon, Malays in Malacca, Ambonese in Ambon, and so forth. Similar to its English counterpart based on the Indian subcontinent, the polycentric Dutch Indian Ocean World littoral of the late eighteenth century consisted of much more 'silt of the land' and much less 'salt of the sea' than the century prior. Whereas in the seventeenth century trade accounted for more than 90 percent of the Company's revenues in Asia, these dropped to about 60 percent in the eighteenth century. Income from taxation, tolls, and other payments became more and more important. ${ }^{69}$ Both 'John Company' and 'Jan Kompenie' were to some extent, effectively reversing the colonial gaze inland turning from maritime merchants into landlords and tax collectors. These seismic changes with multiple epicenters were the harbinger of tidal waves about to sweep both the littoral and interior of the modern Indian Ocean World. 
Table 1. Number of Dutch subjects (including VOC personnel) in the individual 'territorial comptoirs' in the late seventeenth and eighteenth centuries (estimates in italics).

\begin{tabular}{|c|c|c|c|c|}
\hline ‘comptoir' & number (year) & 17th Century Estimate & number (year) & 18 th century estimate \\
\hline Cape Colony & $\begin{array}{l}2,225(1701) \\
2,382(1702) \\
2,578(1703)\end{array}$ & 2,000 & $\begin{array}{l}18,619(1775) \\
23,536(1785) \\
31,792(1795)\end{array}$ & 25,000 \\
\hline Malabar & $12,000(1664)$ & 12,000 & $12,000(1795)$ & 12,000 \\
\hline $\begin{array}{l}\text { Ceylon: } \\
\text { Ceylon 'proper' }\end{array}$ & $\begin{array}{l}230,000 \\
278,098(1684)\end{array}$ & $250,000-300,000$ & $\begin{array}{l}817,000(1789) \\
360,000(1794)\end{array}$ & $\begin{array}{l}360,000- \\
817,000\end{array}$ \\
\hline 'Opposite Coast' & $\begin{array}{l}18,210(1665) \\
20,000(1665)\end{array}$ & & 18,000 & \\
\hline Coromandel & 10,000 & 10,000 & $10,000(1780)$ & 10,000 \\
\hline Malacca & $\begin{array}{l}4,486(1680) \\
5,444(1689) \\
6,000(1707)\end{array}$ & 5,000 & $\begin{array}{l}7,216(1766) \\
14,000(1796)\end{array}$ & 11,000 \\
\hline $\begin{array}{l}\text { Java: } \\
\text { Batavia }\end{array}$ & $\begin{array}{l}20,051(1689) \\
21,911(1699)\end{array}$ & 20,000 & $\begin{array}{l}10,838(1779) \\
7,364(1789) \\
8,497(1797)\end{array}$ & 9,000 \\
\hline Ommelanden & $\begin{array}{l}45,550(1689) \\
49,688(1699)\end{array}$ & 45,000 & $\begin{array}{l}161,215(1779) \\
143,339(1789)\end{array}$ & 150,000 \\
\hline Preanger & 0 & & $\begin{array}{l}99,447(1775) \\
146,700(1808)\end{array}$ & 100,000 \\
\hline Northeast Coast & 0 & 0 & $\begin{array}{l}1,495,908(1796) \\
1,879,559(1802) \\
1,600,000(1807)\end{array}$ & $1,500,000$ \\
\hline Bantam & $\begin{array}{l}810(1689) \\
1,441(1704) \\
1,323(1705)\end{array}$ & 1,000 & $\begin{array}{l}90,000(1775) \\
45,000(1787) \\
90,000(1795) \\
80,000(1807)\end{array}$ & 80,000 \\
\hline Cheribon & 0 & 0 & $\begin{array}{l}90,000(1775) \\
90,000(1795) \\
80,000(1807)\end{array}$ & 90,000 \\
\hline Banda & $\begin{array}{l}6,559(1682) \\
6,634(1689) \\
6,839(1699)\end{array}$ & 6,000 & $\begin{array}{l}6,643(1787) \\
6,020(1790) \\
5,773(1792)\end{array}$ & 6,000 \\
\hline Ambon & $\begin{array}{l}70,027(1689) \\
79,405(1694) \\
76,590(1699)\end{array}$ & 70,000 & $\begin{array}{l}54,641(1780) \\
45,218(1785) \\
53,567(1790)\end{array}$ & 50,000 \\
\hline Ternate & $\begin{array}{l}1,438(1686) \\
2,104(1695) \\
2,285(1699)\end{array}$ & 2,000 & $\begin{array}{l}2,511(1768) \\
2,608(1773) \\
1,603(1779)\end{array}$ & 2,000 \\
\hline
\end{tabular}




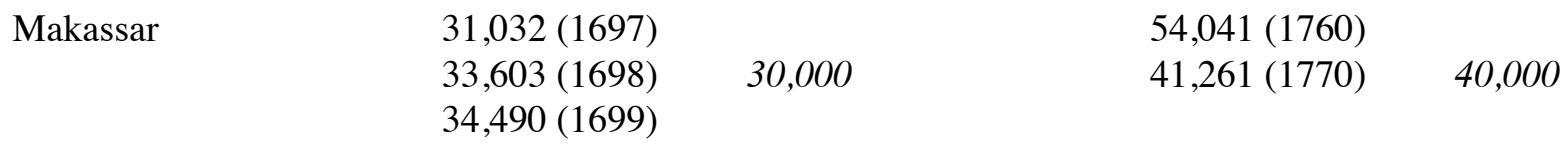

\begin{tabular}{lr}
\hline Estimated total & $453,000-503,000$ \\
& $2,445,000-$ \\
& $2,902,000$ \\
\hline
\end{tabular}

Sources of each individual 'territorial comptoir' are discussed in the relevant section in the body of the text.

Table 2. Total population and composition of select central places in the Dutch Indian Ocean World, 1600-1800 (estimates in italics).

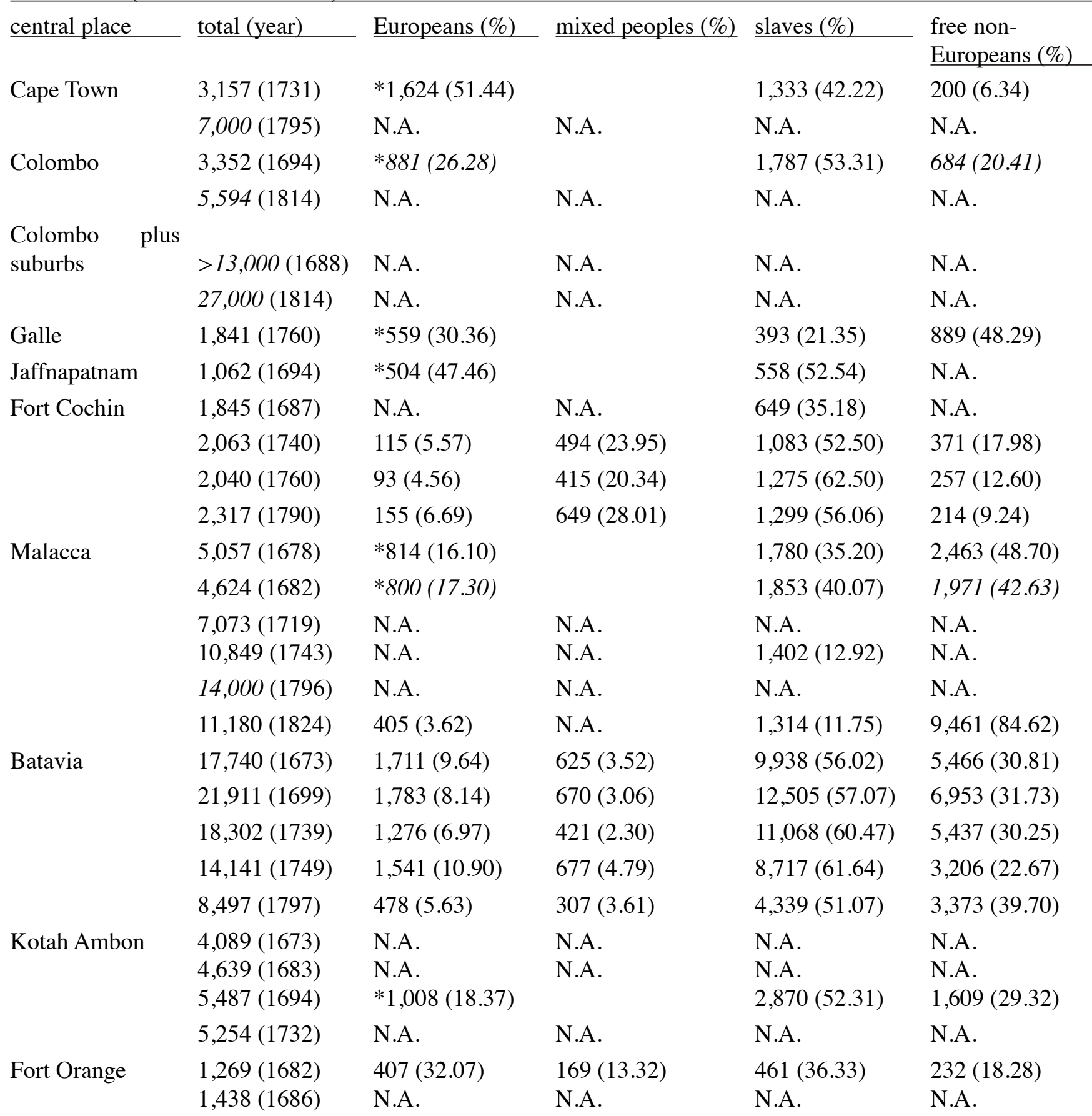




$\begin{array}{llllll} & 2,661(1700) & \text { N.A. } & \text { N.A. } & \text { N.A. } & \text { N.A. } \\ & 2,561(1734) & \text { N.A. } & \text { N.A. } & \text { N.A. } & \text { N.A. } \\ & 2,511(1768) & * * 605(24.09) & & 1,116(44.44) & * * * 790(31.46) \\ & 2,608(1773) & * * 575(22.05) & & 1,138(43.63) & * * * 895(34.32) \\ \text { Vlaardingen } & 1,384(1676) & 69(4.99) & 34(2.46) & 921(66.55) & 360(26.01) \\ \begin{array}{l}\text { Vlaardingen } \\ \text { plus suburbs }\end{array} & 5,622(1701) & \text { N.A. } & \text { N.A. } & \text { N.A. } & \text { N.A. } \\ & 4,983(1730) & * 622(12.48) & & 2,913(58.46) & 1,448(29.06) \\ & 7,640(1791) & \text { N.A. } & \text { N.A. } & \text { N.A. } & \text { N.A. }\end{array}$

*Europeans and mixed peoples combined.

**Families of VOC servants, burghers, and Christian widows combined.

***Families of Chinese, Makassarese, and free servants combined.

Sources of each individual 'territorial comptoir' are discussed in the relevant section in the body of the text. 